\title{
Studi Pemilihan Sistem Pendingin pada Panel Surya Menggunakan Water Cooler, Air Mineral dan Air Laut
}

\author{
Deni Almanda ${ }^{1}$, Doddy Bhaskara ${ }^{2}$ \\ ${ }^{1,2}$ Jurusan Teknik Elektro, Universitas Muhammadiyah Jakarta \\ Jl. Cempaka Putih Tengah 27, Jakarta Pusat 10510 \\ deni.almanda@ftumj.ac.id
}

\begin{abstract}
Abstrak
Permasalahan utama dari solar cell adalah perbedaan jenis solar cell yang mengakibatkan perbedaan kinerja pada solar cell tersebut. Besarnya daya keluaran yang dihasilkan relatif tidak konstan karena dipengaruhi oleh besarnya intensitas matahari serta suhu lingkungan di sekitarnya. Untuk mengatasi masalah tersebut maka penelitian ini dirancang untuk melakukan perbandingan panel surya monocrystalline jenis vertikal dan jenis fleksibel. Dari hasil pengujian dan analisa dengan simulasi pencahayaan matahari langsung menggunakan sistem pendingin panel surya fleksibel menghasilkan efisiensi lebih baik dibanding panel surya vertikal, yaitu $20.40 \%$, sedangkan panel surya vertikal menggunakan heatsink, yaitu 16.75\%. Dari hasil pengujian dan analisa dengan simulasi pencahayaan lampu menggunakan sistem pendingin heatsink panel surya vertikal menghasilkan efisiensi lebih baik dibandingkan dengan panel surya vertikal, yaitu 17.39\%, sedangkan panel surya fleksibel menggunakan heatsink sebesar 15.30\%. Dari hasil pengujian dan Analisa dengan simulasi pencahayaan matahari langsung dengan system tanpa pendingin heatsink telah didapatkan hasil Analisa atau percobaan bahwa panel surya fleksibel menghasilkan efisiensi yang lebih baik dibandingkan panel surya vertikal, yaitu 19.39\%, sedangkan panel surya vertikal mempunyai efisiensi 18.55\%. dari hasil percobaan dan Analisa dengan simulasi pencahayaan lampu tanpa menggunakan system pendingin heatsink dari hasil percobaan dan Analisa telah didapatkan bahwa panel surya vertikal menghasilkan efisiensi yang lebih baik dari pada panel surya fleksibel, yaitu $18.50 \%$, sedangkan panel surya fleksibel menghasilkan efisiensi sebesar $17.37 \%$.
\end{abstract}

Kata Kunci : Panel Surya, Panel Surya Vertikal, Panel Surya Fleksibel, Efisiensi.

\section{PENDAHULUAN}

Energi matahari dimanfaatkan sebagai sumber energi alternatif yang potensial, terutama dilihat dari sumbernya yang memancarkan energi yang sangat besar serta waktunya yang panjang. Selain itu diharapkan energi matahari dapat dimanfaatkan sebagai sumber energi listrik yang ramah lingkungan, sehingga apabila energi ini dapat dikelola dengan baik, diharapkan kebutuhan masyarakat akan energi dapat terpenuhi. Banyak sekali perusahaan start up fotovoltik yang menarik investasi dari para kapitalis dan bahkan perusahaan minyak [1].

Sel surya adalah sebuah elemen semikonduktor yang dapat mengkonversi energy surya menjadi energy listrik dengan prinsip fotovoltaik [2]. Modul surya adalah kumpulan beberapa sel surya, dan panel surya adalah kumpulan beberapa modul surya. Intensitas radiasi cahaya matahari yang diterima sel surya sebanding dengan tegangan dan arus listrik yang dihasilkan oleh sel surya, sedangkan apabila suhu lingkungan semakin tinggi dengan intensitas radiasi cahaya matahari yang tetap, maka tegangan panel surya akan berkurang dan arus listrik yang dihasilkan akan bertambah. Perubahan temperatur sel-sel surya ini diakibatkan oleh temperatur, kondisi awan dan kecepatan angin di lingkungan sekitar daerah penempatan panel surya. Pengurangan ketebalan wafer silikon telah berkembang di dalam industry solar [3]. Fotovoltik yang bersifat mobile adalah teknologi yang bisa mengurangi resupply bahan bakar [4]. Sel surya polimer bisa diproses dari solusi yang menawarkan poteni teknologi yang penting untuk fabrikasi dengan biaya rendah pada substrat yang luas dan fleksibel [5].

Panel surya bisa ditingkatkan efisiensinya dengan cara menambahkan reflektor atau konsentrator. Reflektror atau konsentrator pada panel sel surya berbentuk seperti cermin yang difungsikan sebagai pemantul dan pemfokus cahaya matahari ke panel sel surya. Saat ini mikrokontroler dipakai untuk mencari energi maksimum [6]. Pemantulan cahaya Pemantulan cahaya matahari ini akan membuat intensitas cahaya matahari lebih terkonsentrasi pada panel sel surya sehingga energi listrik yang di keluarkan panel sel surya menjadi semakin besar. Peningkatan daya keluaran pada panel sel surya ini akan meningkat menjadi sekitar 46\%. Meskipun penambahan reflektor atau konsentrator pada panel sel surya dapat menambah performa panel sel surya, tetapi teknik ini ternyata 
RESISTOR (elektRonika kEndali telekomunikaSI tenaga liSTrik kOmputeR) Vol. 1 No. 2 e-ISSN : 2621-9700, p-ISSN : 2654-2684

juga memiliki kelemahan. Akibat dari pengonsentrasian intensitas cahaya ini adalah berimbas pada temperatur panel sel surya yang akan meningkat cepat. Peningkatan temperatur ini dapat berpengaruh pada daya keluaran yang dihasilkan panel sel surya. Setiap kenaikan temperatur panel surya $1{ }^{\circ} \mathrm{C}$ (dari $25^{\circ} \mathrm{C}$ ). Akan mengakibatkan berkurangnya sekitar $0,5 \%$ pada total tenaga yang dihasilkan. Suhu atau temperatur udara yang tinggi dapat mempengaruhi kinerja panel surya [7]. Dalam hal ini system pendingin tersebut mengurangi tingkat kepanasan pada panel surya dan meningkatkan efisiensi tegangan yang masuk pada pendingin pada panel surya. Selain suhu, bayangan penghalang juga bisa mengurangi keluarah panel surya dan ini bisa diantisipasi dengan memakai dioda bypass [8].

Hal ini yang melandasi penulis untuk merancang dan meneliti suatu penelitian yaitu " STUDI PEMILIHAN SISTEM PENDINGIN PADA PANEL SURYA MENGGUNAKAN WATER COOLER, AIR MINERAL DAN AIR

LAUT “. Dari hasil penelitian ini diharapkan bisa diketahui seberapa efisien penggunaan sistem pendingin Photovoltaic tersebut.

Tujuan penelitian ini adalah untuk mengetahui perbandingan antara tiga karakteristik system temperature pendingin panel surya menggunakan water cooling, air mineral, dan air laut guna pengoptimalkan pendingin terhadap surya panel untuk mendapatkan efisiensi temperature pendingin yang terbaik.

Rumusan masalah pada penelitian ini diantaranya sebagai berikut :

1. Bagaimana merancang suatu system temperature pendingin Panel Surya menggunakan water coolant, air mineral dan air laut.

2. Dapat mengetahui perbandingan efisiensi tegangan, arus, daya, dan temperature tiap sisi pada permukaan panel surya menggunakan water cooling, Air Mineral, dan Air Laut untuk kinerja dari panel surya tersebut.

Agar penelitian ini terfokus pada permasalahan, maka ruang lingkup penelitian ini dibatasi pada:

1. Jenis photovoltaic yang digunakan jenis photovoltaic monocrystalline $20 \mathrm{Wp}$.

2. Daya photovoltaic yang digunakan sebesar 20 Wp untuk monocristalline.

3. Penggunaan Aki atau baterai sebagai media penyimpan energi listrik.

4. Pengontrollan output dari solar panel surya ke battery dan output dari panel surya ke beban menggunakan Solar Charge Controller.
5. Photovoltaic dipasang Water Coolant, Air Mineral, dan Air Laut sebagai sistem pendingin photovoltaic.

6. Penyinaran cahaya menggunakan pencahyaaan matahari langsung.

7. Penilitian ini difokuskan pada efisiensi solar cell, arus (A), tegangan (V), intensitas cahaya $\left(\mathrm{W} / \mathrm{m}^{2}\right)$, Daya $(\mathrm{P})$, dan efisiensi panel surya

\section{METODOLOGI}

Sel surya (Photovoltaic-PV) merupakan salah satu teknologi semikonduktor yang dikembangkan sebagai pembangkit tenaga listrik. Prinsip dasar PV merupakan kebalikan dari LED (Light Emmiting Diode) yang mengubah energi listrik menjadi cahaya atau dapat dikatakan identik dengan sebuah dioda cahaya (photodiode) hubungan $\mathrm{p}-\mathrm{n}$ ( $\mathrm{p}-\mathrm{n}$ junction). Ketika energi foton yang datang lebih besar dari celah energi ini, maka foton akan diserap oleh semikonduktor untuk membentuk pasangan elektron-hole sebagai pembawa muatan (carrier). Selanjutnya elektron dan hole bergerak berturutturut ke arah lapisan semikonduktor $p$ dan semikonduktor $\mathrm{n}$ sehingga timbul beda potensial dan photocurrent (arus yang dihasilkan oleh cahaya). Gambar 2.1. menjelaskan proses arus dan elektron pada pembangkitan sel surya.

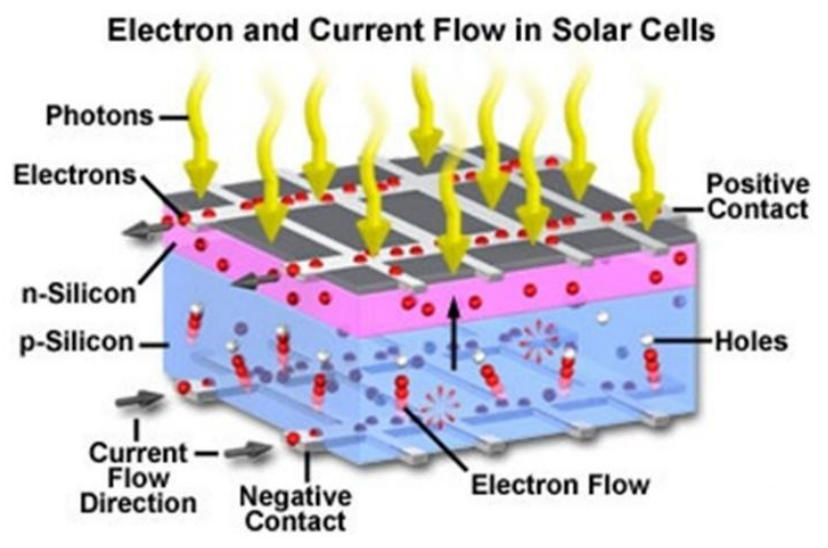

Gambar 1. Proses arus dan electron pada panel surya.

Perancangan

- Simulasi Perbandingan Sistem Pendingin Panel Surya Menggunakan Water Coolant dengan Penyinaran Matahari Langsung.

Simulasi ini dilakukan untuk mencari tegangan, arus dan suhu yang masuk. Cara yang dilakukan dalam simulasi dapat dilihat pada gambar 
RESISTOR (elektRonika kEndali telekomunikaSI tenaga liSTrik kOmputeR) Vol. 1 No. 2 e-ISSN : 2621-9700, p-ISSN : 2654-2684

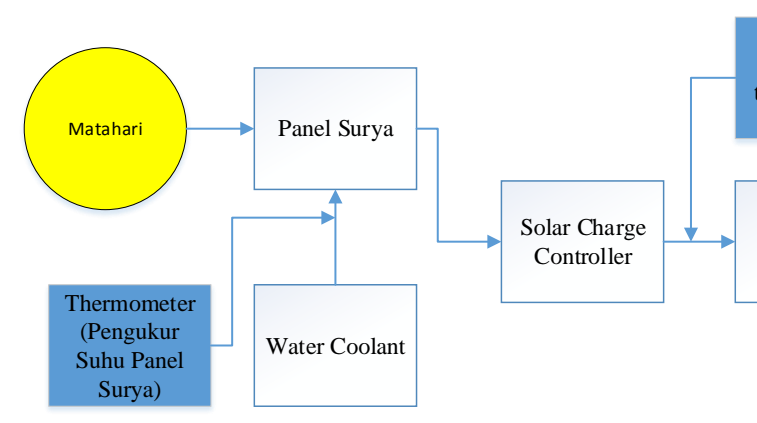

Gambar 2. Simulasi system pendingin panel surya menggunakan water coolant dengan penyinaran matahari langsung.

- Simulasi Perbandingan Sistem Pendingin Panel Surya Menggunakan Air Mineral dengan Penyinaran Matahari Langsung.

Simulasi ini dilakukan untuk mencari tegangan, arus dan suhu yang masuk. Cara yang dilakukan dalam simulasi dapat dilihat pada gambar

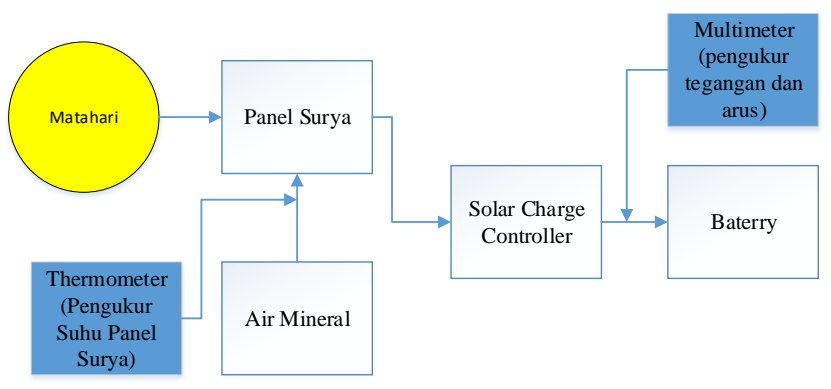

Gambar 3. Simulasi system pendingin panel surya menggunakan air mineral dengan penyinaran matahari langsung.

- Simulasi system pendingin panel surya menggunakan Air Laut dengan penyinaran matahari langsung

Simulasi ini dilakukan untuk mencari tegangan, arus dan suhu yang masuk. Cara yang dilakukan dalam simulasi dapat dilihat pada gambar

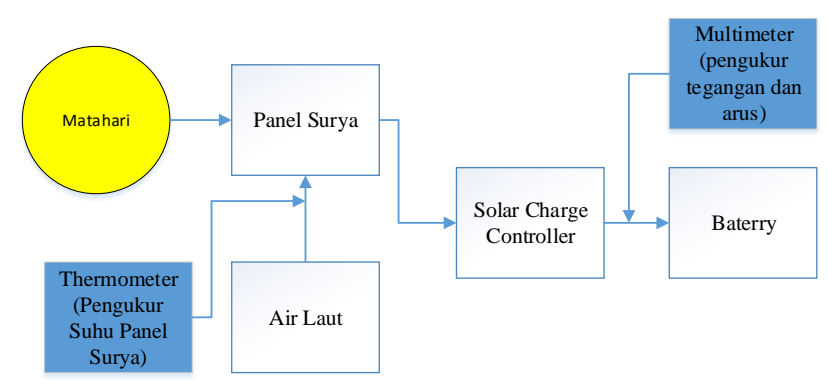

Gambar 4. Simulasi system pendingin panel surya menggunakan air laut dengan penyinaran matahari langsung.

\section{- Diagram Pengujian}

Urutan pengujian dan analisa data yang dituangkan dalam alur diagram seperti dibawah yakni pengujian diawali dari merancang design panel surya dengan sistem pendingin water coolant, air mineral, dan air laut dengan kondisi penyinaran matahari langsung. Pada saat dipasang dapat kita ketahui bahwa perbandingan pada panel sel surya Jenis Monocrytalline menggunakan sistem pendingin water coolant, air mineral, dan air laut. dengan kondisi penyinaran matahari langsung dapat mengetahui efisiensi dari kedua pendingin tersebut. sehingga kita dapat mengetahui perbandingan tegangan, arus dan suhu keluaran panel surya Jenis Monocrystalline pada saat menggunakan sistem pendingin panel surya.

Pengujian sendiri dilakukan dengan mengamati Tegangan (Volt) dan nilai Arus (Ampere) dan Suhu (T). Kemudian dapat diketahui juga daya yang dihasilkan sistem pendingin panel surya yang telah diukur dengan menggunakan Watt Meter.

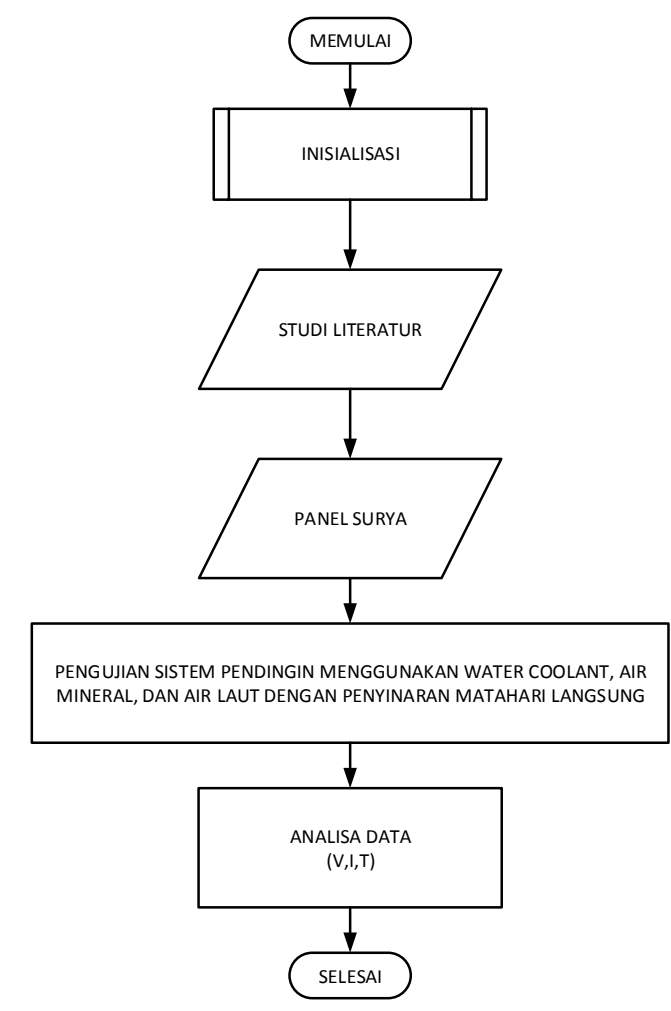

Gambar 5. Diagram Pengujian.

- Pengujian dan Analisa

$\checkmark$ Tujuan Pengujian 
RESISTOR (elektRonika kEndali telekomunikaSI tenaga liSTrik kOmputeR) Vol. 1 No. 2 e-ISSN : 2621-9700, p-ISSN : 2654-2684

Pengujian dilakukan dengan tujuan untuk mengetahui karakteristik, output yang dihasilkan, dan perbandingan output daya yang dihasilkan panel surya menggunakan system pendingin water coolant, air mineral, dan air laut pada saat pencahayaan matahari secara langsung.

\section{$\checkmark$ Target Pengujian}

Menguji perbedaan karakteristik dan perbedaan output antara panel surya menggunakan pendingin water coolant, air mineral, dan air laut dengan menggunakan pencahayaan matahari secara langsung.

\section{$\checkmark$ Waktu Pengujian dan Pengambilan Data} 2018

Tanggal Pengujian: 20 Mei 2018 s/d 08 Juli

Lokasi : Rooftop Fakultas Teknik Universitas Muhammdiyah Jakarta

Pukul: 09.00 WIB s/d 16.00 WIB

- Desain dan Ilustrasi Penelitian Sistem Pendingin Panel Surya dengan Menggunakan water coolant, air mineral, dan air laut.

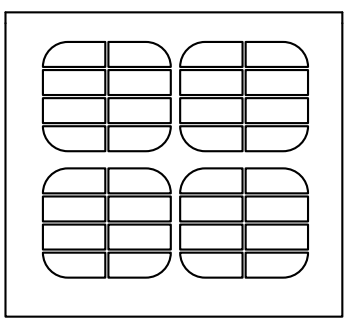

TAMPAK DEPAN

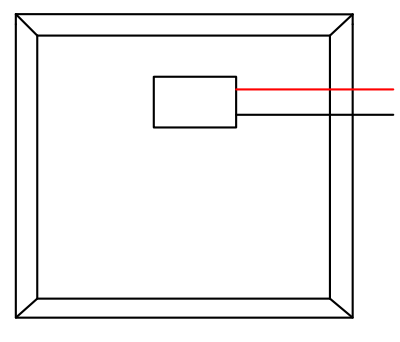

TAMPAK BELAKANG
Gambar 6. Desain dan ilustrasi penelitian system pendingin panel surya

- Ilustrasi Pengambilan Data Temperatur Panel Surya Monocrystaline 20Wp

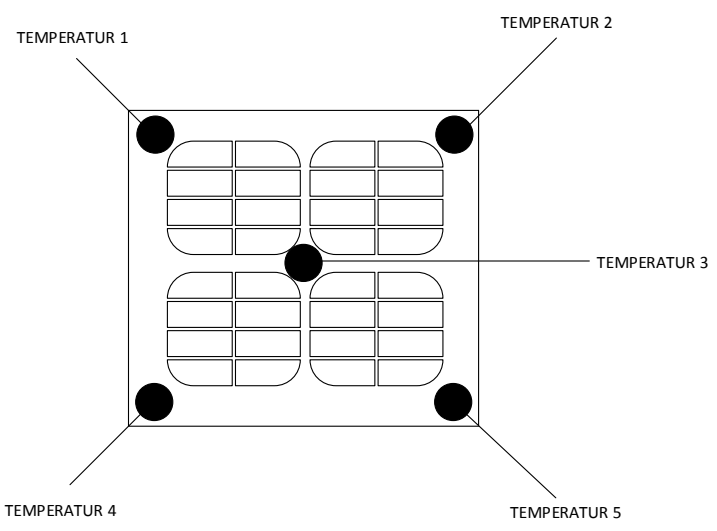

Gambar 7. Ilustrasi pengambilan data temperatur panel surya.
- Ilustrasi Pengambilan Data Sistem Pendingin Menggunakan Water Coolant, Air Mineral, dan Air Laut.
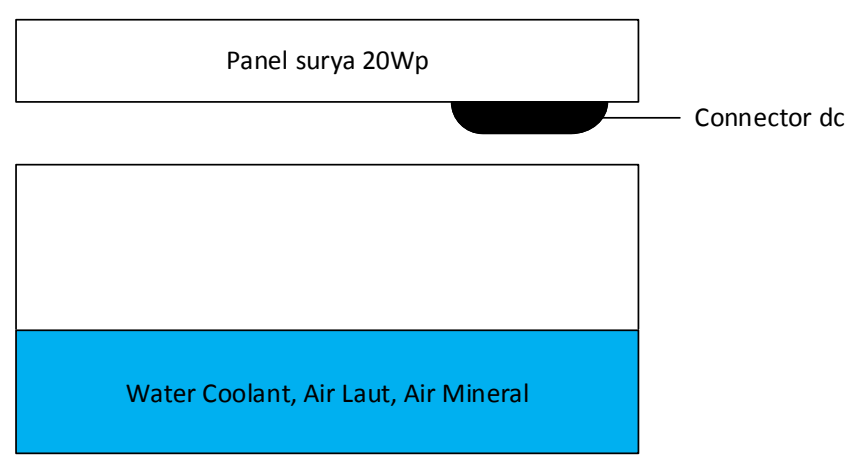

Gambar 8. Ilustrasi pengambilan data system pendingin menggunakan water coolant, air mineral, dan air laut.

\section{HASIL DAN ANALISA}

- Hasil Pengujian Panel Surya menggunakan water coolant pada pencahayaan matahari langsung.

Pengujian dengan penyinaran matahari langsung dilakukan dan dianalisa dengan jeda waktu 30 menit. Pengujian dilakukan dengan waktu dan tempat yang bersamaan untuk mendapatkan kondisi pencahayan matahari yang sama antara panel surya dengan system pendingin water coolant yang bertujuan untuk melihat kinerja panel surya menggunakan system pendingin water coolant.

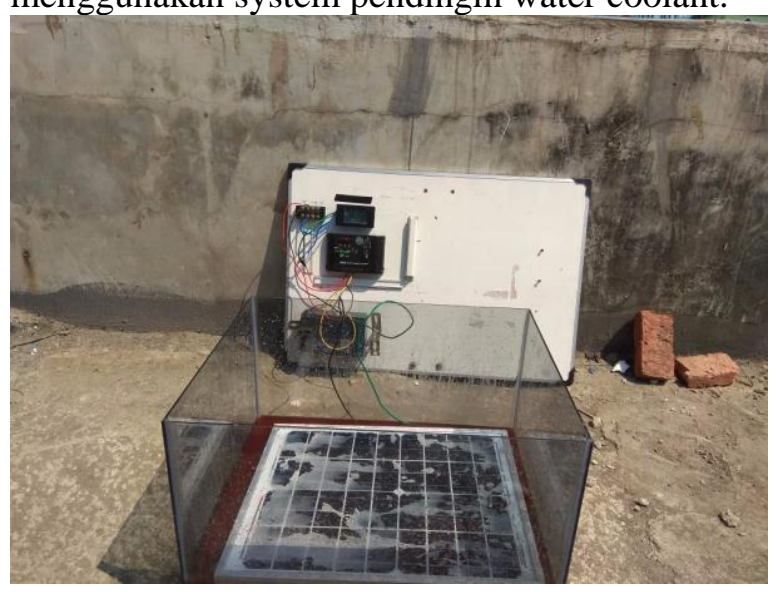

Gambar 9. Pengujian Sistem Pendingin panel surya menggunakan Water Coolant pada penyinaran matahari langsung

Tabel 1. Pengujian Sistem Pendingin panel surya menggunakan water coolant pada penyinaran matahari langsung 
RESISTOR (elektRonika kEndali telekomunikaSI tenaga liSTrik kOmputeR) Vol. 1 No. 2 e-ISSN : 2621-9700, p-ISSN : 2654-2684

\begin{tabular}{|c|c|c|c|c|c|}
\hline Waktu & $\begin{array}{c}\text { Intensitas } \\
\text { Cahaya } \\
\left(\mathrm{W} / \mathrm{m}^{2}\right)\end{array}$ & $\begin{array}{c}\text { Tegangan } \\
\text { (V) }\end{array}$ & $\begin{array}{l}\text { Arus } \\
\text { (A) }\end{array}$ & $\begin{array}{l}\text { Daya } \\
(W)\end{array}$ & efisiensi \\
\hline 09.30 & 633 & 19.59 & 0.71 & 13.91 & $14.60 \%$ \\
\hline 10.00 & 755 & 19.57 & 0.69 & 13.50 & $11.88 \%$ \\
\hline 10.30 & 760 & 19.51 & 0.67 & 13.07 & $11.43 \%$ \\
\hline 11.00 & 782 & 19.47 & 0.65 & 12.66 & $10.75 \%$ \\
\hline 11.30 & 769 & 19.41 & 0.63 & 12.23 & $10.57 \%$ \\
\hline 12.00 & 775 & 19.36 & 0.6 & 11.62 & $9.96 \%$ \\
\hline 12.30 & 763 & 19.28 & 0.59 & 11.38 & $9.91 \%$ \\
\hline 13.00 & 812 & 19.18 & 0.55 & 10.55 & $8.63 \%$ \\
\hline 13.30 & 749 & 18.93 & 0.54 & 10.22 & $9.07 \%$ \\
\hline 14.00 & 743 & 18.98 & 0.56 & 10.63 & $9.51 \%$ \\
\hline 14.30 & 723 & 19.09 & 0.58 & 11.07 & $10.18 \%$ \\
\hline 15.00 & 718 & 19.16 & 0.62 & 11.88 & $10.99 \%$ \\
\hline 15.30 & 607 & 19.31 & 0.64 & 12.36 & $13.53 \%$ \\
\hline 16.00 & 588 & 19.38 & 0.63 & 12.21 & $13.80 \%$ \\
\hline Rata - Rata & 726.9 & 19.30 & 0.62 & 11.95 & $11.06 \%$ \\
\hline
\end{tabular}

Untuk menentukan efisiensi yang terdapat pada tabel 1. data didapatkan dari hasil pengujian yang telah dilakukan, digunakan sebagai berikut:

Rumus perhitungan efisiensi:

$\eta$

$=\frac{P \max (\text { maximum power point })}{E \text { (incident radiation flix) } \times \text { Ac (area of colecto }}$ Dimana :

$\eta=$ Efisiensi $(\%)$

Pmax $=$ Maximum Power Point $(\mathrm{W})$

$\mathrm{E}=$ Radiasi Matahari $\left(\mathrm{W} / \mathrm{m}^{2}\right)$

$\mathrm{A}_{\mathrm{c}}=$ Luas Permukaan Panel Surya $\left(\mathrm{m}^{2}\right)$

$\eta=\frac{13,91 \mathrm{Watt}}{633 \times(0,43 \times 0,35)} \times 100 \%$

$\eta=\frac{13,91}{95,2665} \times 100 \%$

$\eta=14,60 \%$

- Hasil Pengujian Sistem Pendingin Panel Surya Menggunakan Air Mineral dengan penyinaran matahari langsung.

Pengujian dengan penyinaran matahari langsung dilakukan dan dianalisa dengan jeda waktu 30 menit. Pengujian dilakukan dengan waktu dan tempat yang bersamaan untuk mendapatkan kondisi pencahayan matahari pada sistem pendingin panel surya menggunakan air mineral yang bertujuan untuk melihat kinerja panel surya menggunakan air mineral. Sebelum pengujian air mineral di ukur kadar $\mathrm{PH}$ air mineral terhadap panel surya dengan nilai kadar PH 7.4. Berikut adalah kadar PH dan gambar pengujian panel surya menggunakan air mineral pada pencahayaan matahari langsung.

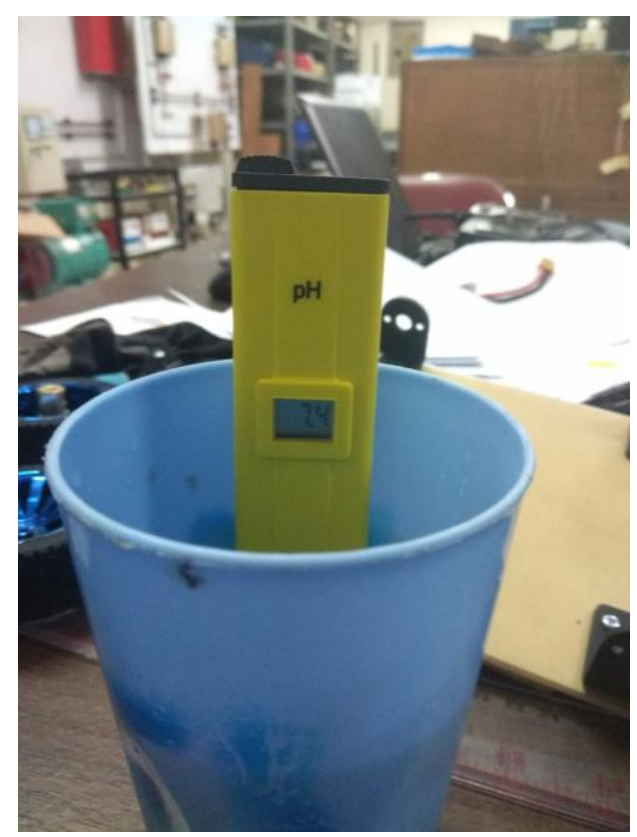

Gambar 10. Pengujian kadar ph air mineral

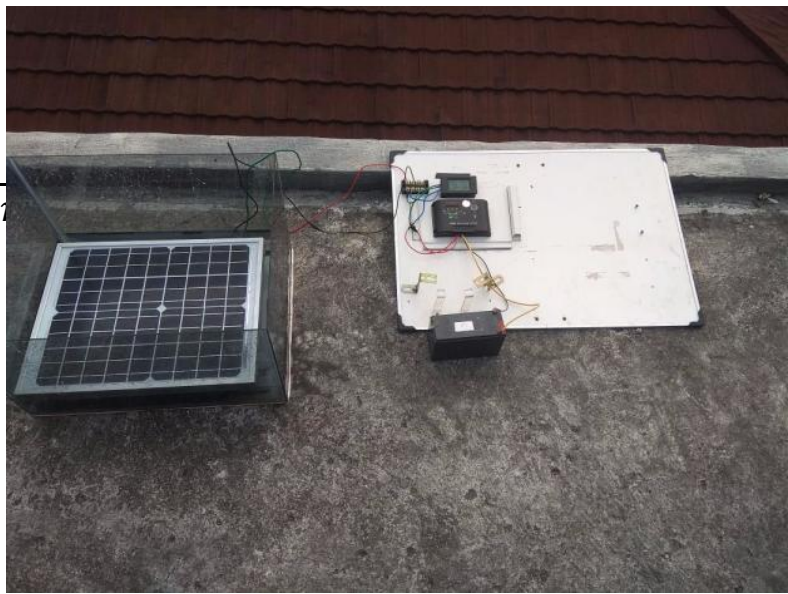

Gambar 11. Pengujian system pendingin panel surya menggunakan air mineral pada pencahayaan matahari langsung.

Tabel 2. Pengujian system pendingin panel surya menggunakan air mineral pada pencahayaan matahari langsung 
RESISTOR (elektRonika kEndali telekomunikaSI tenaga liSTrik kOmputeR) Vol. 1 No. 2 e-ISSN : 2621-9700, p-ISSN : 2654-2684

\begin{tabular}{|c|c|c|c|c|c|}
\hline Waktu & $\begin{array}{l}\text { Intensitas } \\
\text { Cahaya } \\
\left(\mathrm{W} / \mathrm{m}^{2}\right)\end{array}$ & $\begin{array}{l}\text { Teganga } \\
n(V)\end{array}$ & $\begin{array}{l}\text { Arus } \\
\text { (A) }\end{array}$ & $\begin{array}{l}\text { Daya } \\
\text { (W) }\end{array}$ & Efisiensi \\
\hline 09.30 & 633 & 19.47 & 0.68 & 13.24 & $13.90 \%$ \\
\hline 10.00 & 755 & 19.44 & 0.67 & 13.02 & $11.46 \%$ \\
\hline 10.30 & 760 & 19.39 & 0.64 & 12.41 & $10.85 \%$ \\
\hline 11.00 & 782 & 19.25 & 0.62 & 11.94 & $10.14 \%$ \\
\hline 11.30 & 769 & 19.21 & 0.59 & 11.33 & $9.79 \%$ \\
\hline 12.00 & 775 & 19.17 & 0.56 & 10.74 & $9.20 \%$ \\
\hline 12.30 & 763 & 19.15 & 0.53 & 10.15 & $8.84 \%$ \\
\hline 13.00 & 812 & 19.03 & 0.51 & 9.71 & $7.94 \%$ \\
\hline 13.30 & 749 & 18.81 & 0.5 & 9.41 & $8.34 \%$ \\
\hline 14.00 & 743 & 18.78 & 0.53 & 9.95 & $8.90 \%$ \\
\hline 14.30 & 723 & 18.93 & 0.55 & 10.41 & $9.57 \%$ \\
\hline 15.00 & 718 & 19.08 & 0.56 & 10.68 & $9.89 \%$ \\
\hline 15.30 & 607 & 19.11 & 0.57 & 10.89 & $11.92 \%$ \\
\hline 16.00 & 588 & 19.14 & 0.58 & 11.10 & $12.54 \%$ \\
\hline Rata - Rata & $\begin{array}{c}726.9285 \\
7\end{array}$ & 19.14 & 0.58 & 11.07 & $10.24 \%$ \\
\hline
\end{tabular}

Untuk menentukan efisiensi yang terdapat pada tabel 4.2 data didapatkan dari hasil pengujian yang telah dilakukan, digunakan sebagai berikut: Rumus perhitungan efisiensi:

$\eta$

$=\frac{P \max (\text { maximum power point })}{E \text { (incident radiation flix) } \times \text { Ac (area of colector })} \times 100 \%$ Dimana :

$\eta=$ Efisiensi $(\%)$

Pmax = Maximum Power Point $(\mathrm{W})$

$\mathrm{E}=$ Radiasi Matahari $\left(\mathrm{W} / \mathrm{m}^{2}\right)$

$\mathrm{A}_{\mathrm{c}}=$ Luas Permukaan Panel Surya $\left(\mathrm{m}^{2}\right)$

$\eta=\frac{13,24 \text { Watt }}{633 \times(0,43 \times 0,35)} \times 100 \%$

$\eta=\frac{13,24}{95,2665} \times 100 \%$

$\eta=13,90 \%$

- Hasil pengujian system pendingin panel surya menggunakan air laut pada penyinaran matahari langsung.

Pengujian dengan penyinaran matahari langsung dilakukan dan dianalisa dengan jeda waktu 30 menit. Pengujian dilakukan dengan waktu dan tempat yang bersamaan untuk mendapatkan kondisi pencahayan matahari pada sistem pendingin panel surya menggunakan air laut yang bertujuan untuk melihat kinerja panel surya menggunakan air laut. Sebelum pengujian air laut di ukur kadar PH air laut terhadap panel surya dengan kadar PH air laut sebesar 8.0. Berikut adalah kadar PH dan gambar pengujian panel surya menggunakan air laut pada pencahayaan matahari langsung.

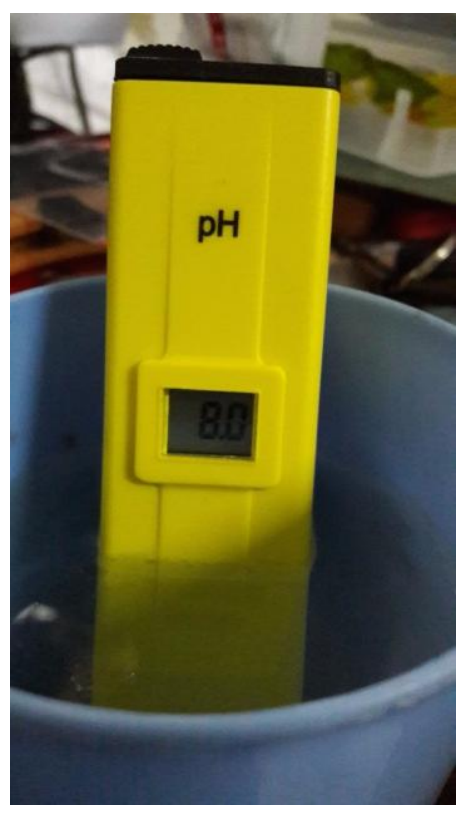

Gambar 12. Pengujian kadar ph Air Laut.

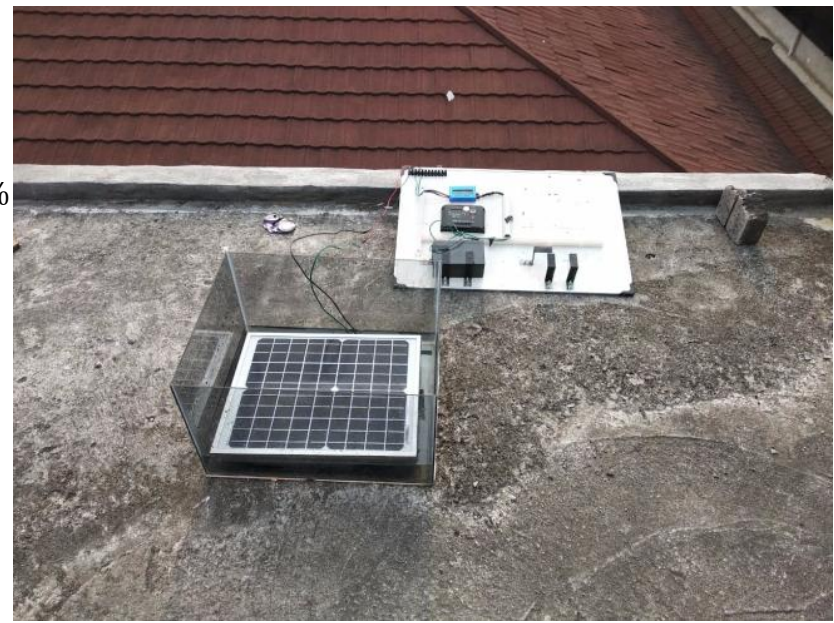

Gambar 13. Pengujian Sistem Pendingin Panel Surya Menggunakan Air Laut pada penyinaran matahari langsung

Tabel 3. Pengujian system pendingin panel surya menggunakan air laut pada penyinaran matahari langsung. 
RESISTOR (elektRonika kEndali telekomunikaSI tenaga liSTrik kOmputeR) Vol. 1 No. 2 e-ISSN : 2621-9700, p-ISSN : 2654-2684

\begin{tabular}{|c|c|c|c|c|c|}
\hline Waktu & $\begin{array}{c}\text { Intensitas } \\
\text { Cahaya }\left(W / \mathrm{m}^{2}\right)\end{array}$ & $\begin{array}{c}\text { Tegangan } \\
\text { (V) }\end{array}$ & $\begin{array}{l}\text { Arus } \\
\text { (A) }\end{array}$ & $\begin{array}{l}\text { Daya } \\
\text { (W) }\end{array}$ & Efisiensi \\
\hline 09.30 & 633 & 19.37 & 0.67 & 12.98 & $13.62 \%$ \\
\hline 10.00 & 755 & 19.33 & 0.66 & 12.76 & $11.23 \%$ \\
\hline 10.30 & 760 & 19.23 & 0.64 & 12.31 & $10.76 \%$ \\
\hline 11.00 & 782 & 19.14 & 0.61 & 11.68 & $9.92 \%$ \\
\hline 11.30 & 769 & 19.05 & 0.57 & 10.86 & $9.38 \%$ \\
\hline 12.00 & 775 & 18.98 & 0.53 & 10.06 & $8.62 \%$ \\
\hline 12.30 & 763 & 18.93 & 0.56 & 10.60 & $9.23 \%$ \\
\hline 13.00 & 812 & 18.85 & 0.52 & 9.80 & $8.02 \%$ \\
\hline 13.30 & 749 & 18.77 & 0.51 & 9.57 & 8. $49 \%$ \\
\hline 14.00 & 743 & 18.69 & 0.52 & 9.72 & $8.69 \%$ \\
\hline 14.30 & 723 & 18.89 & 0.52 & 9.82 & $9.03 \%$ \\
\hline 15,00 & 718 & 18.92 & 0.53 & 10.03 & $9.28 \%$ \\
\hline 15.30 & 607 & 19.02 & 0.55 & 10.46 & $11.45 \%$ \\
\hline 16.00 & 588 & 19.06 & 0.56 & 10.67 & $12.06 \%$ \\
\hline lata - Rata & 726.9285714 & 19.02 & 0.57 & 10.81 & $9.99 \%$ \\
\hline
\end{tabular}

Untuk menentukan efisiensi yang terdapat pada tabel 4.3 data didapatkan dari hasil pengujian yang telah dilakukan, digunakan sebagai berikut: Rumus perhitungan efisiensi:

$\eta$

$$
=\frac{P \max (\text { maximum power point) }}{E \text { (incident radiation flix) } x \text { Ac (area of colect } \mathrm{C}}
$$
Dimana :

$\eta=$ Efisiensi $(\%)$

Pmax $=$ Maximum Power Point $(\mathrm{W})$

$\mathrm{E}=$ Radiasi Matahari $\left(\mathrm{W} / \mathrm{m}^{2}\right)$

$\mathrm{A}_{\mathrm{c}}=$ Luas Permukaan Panel Surya $\left(\mathrm{m}^{2}\right)$

$\eta=\frac{12,98 \mathrm{Watt}}{633 \times(0,43 \times 0,35)} \times 100 \%$

$\eta=\frac{12,98}{95,2665} \times 100 \%$

$\eta=13,62 \%$

Agar memudahkan untuk melihat perbedaan

dari hasil pengujian antara panel surya menggunakan system pendingin water coolant, air mineral, dan air laut pada penyinaran matahari langsung yang dapat dilihat pada tabel 1, tabel 2, dan table 3. maka perbedaan itu digambarkan dalam bentuk grafik seperti pada dibawah ini.

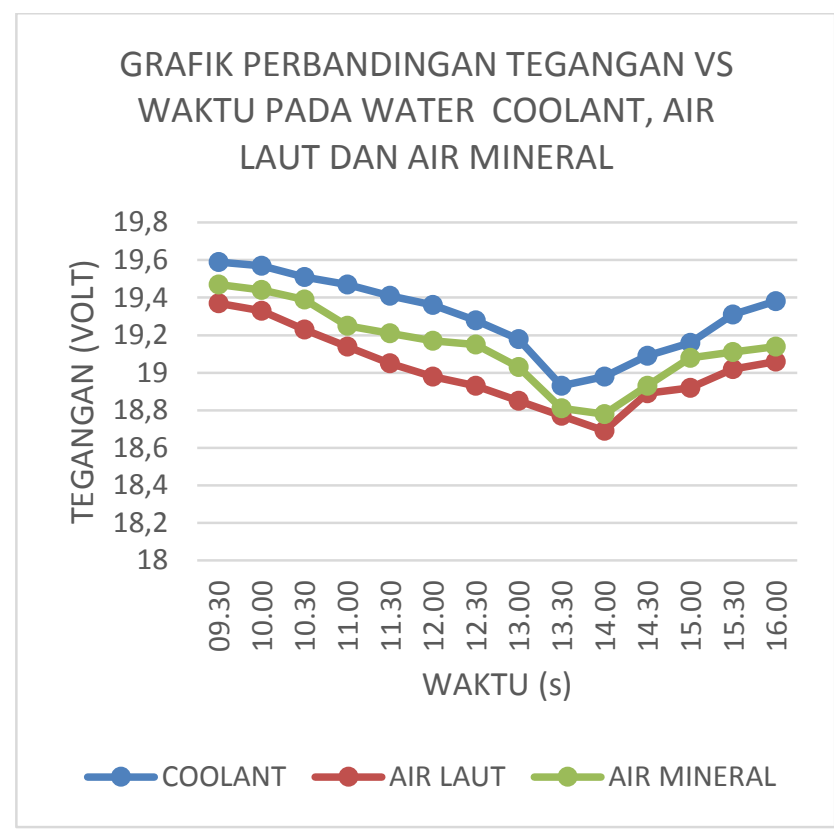

Gambar 14. Grafik perbedaan Tegangan vs Waktu panel surya menggunakan system pendingin water coolant, air mineral, dan air laut dengan pencahayaan matahari langsung.

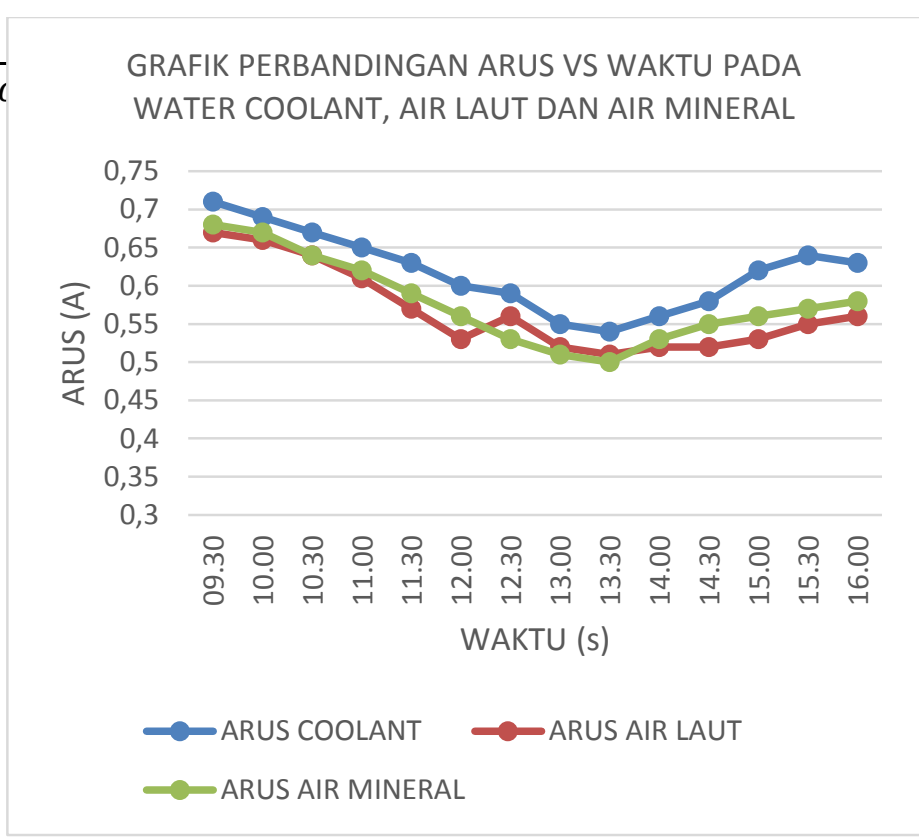

Gambar 15. Grafik perbedaan Arus vs Waktu panel surya menggunakan system pendingin water coolant, air mineral, dan air laut dengan pencahayaan matahari langsung. 
RESISTOR (elektRonika kEndali telekomunikaSI tenaga liSTrik kOmputeR) Vol. 1 No. 2 e-ISSN : 2621-9700, p-ISSN : 2654-2684

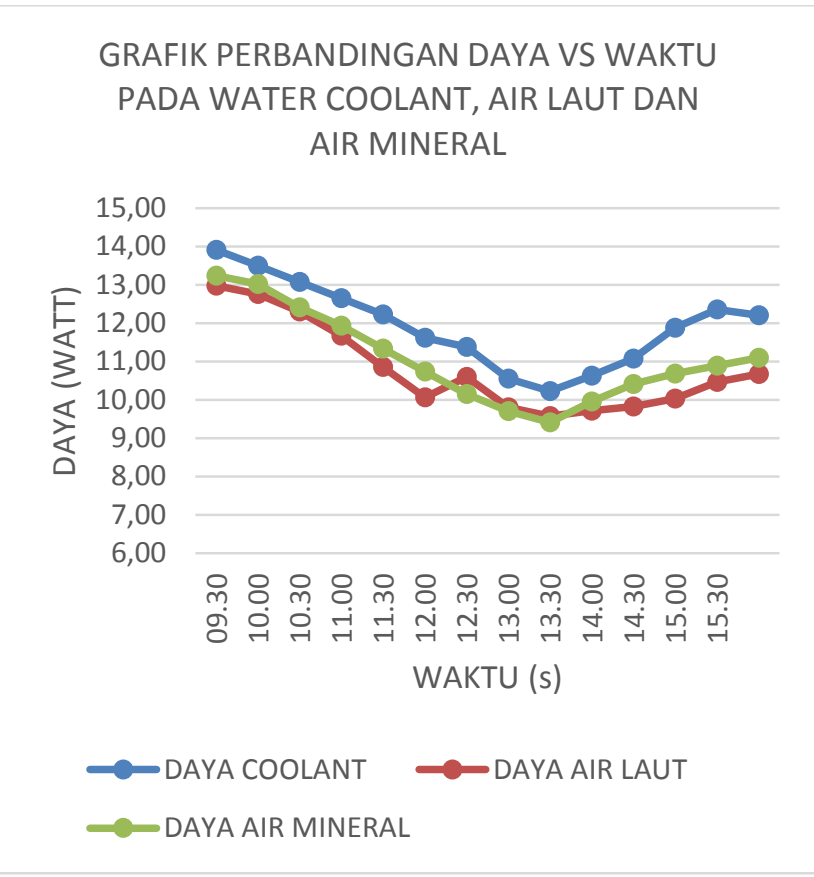

Gambar 16. Grafik perbedaan Daya vs Waktu panel surya menggunakan system pendingin water coolant, air mineral, dan air laut dengan pencahayaan matahari langsung.

\section{GRAFIK EFISIENSI VS WAKTU PADA WATER COOLANT, AIR LAUT DAN AIR MINERAL}

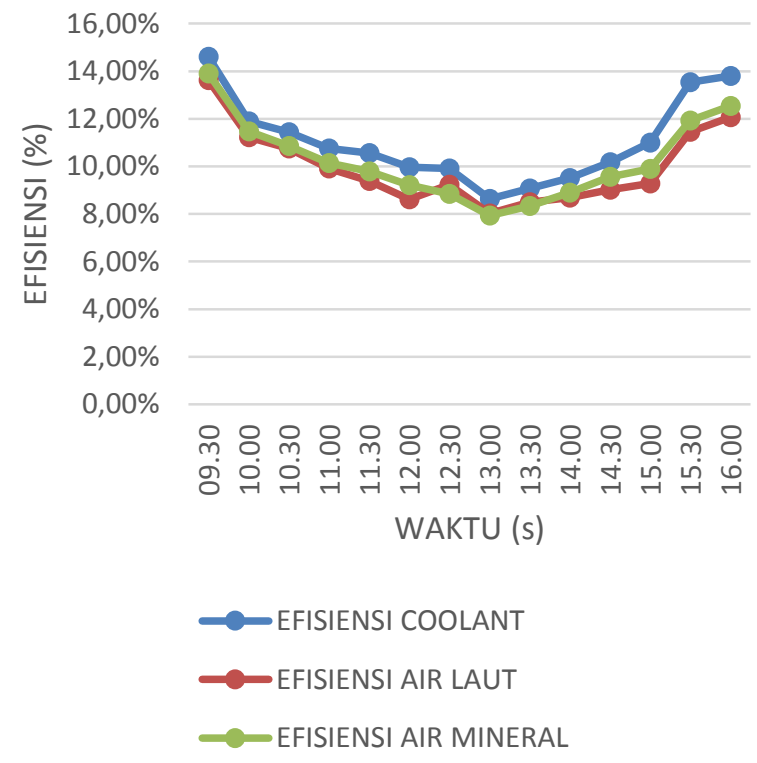

Gambar 17. Grafik perbedaan Efisiensi vs Waktu panel surya menggunakan system pendingin water coolant, air mineral, dan air laut dengan pencahayaan matahari langsung.

Tabel 4. Hasil Pengujian Suhu permukaan panel surya menggunakan water coolant pada penyinaran matahari langsung

\begin{tabular}{|c|c|c|c|c|c|}
\hline \multicolumn{7}{|c|}{ Suhu Panel Photovoltaic Menggunakan Sistem Pendingin Coolant } \\
\hline Waktu (s) & $\begin{array}{c}\text { Termometer } 1 \\
\left({ }^{\circ} \mathrm{C}\right)\end{array}$ & $\begin{array}{c}\text { Termometer } 2 \\
\left({ }^{\circ} \mathrm{C}\right)\end{array}$ & $\begin{array}{c}\text { Termometer } \\
3\left({ }^{\circ} \mathrm{C}\right)\end{array}$ & $\begin{array}{c}\text { Termometer 4 } \\
\left({ }^{\circ} \mathrm{C}\right)\end{array}$ & $\begin{array}{c}\text { Termometer } \\
5\left({ }^{\circ} \mathrm{C}\right)\end{array}$ \\
\hline $\mathbf{0 9 . 0 0}$ & 28.8 & 36.7 & 39.5 & 38.7 & 31.3 \\
\hline $\mathbf{0 9 . 3 0}$ & 30.6 & 31.5 & 38.3 & 40.3 & 32.5 \\
\hline $\mathbf{1 0 . 0 0}$ & 29.8 & 44.7 & 36.2 & 41.4 & 33.9 \\
\hline $\mathbf{1 0 . 3 0}$ & 34 & 32.7 & 41.9 & 40.8 & 35.7 \\
\hline $\mathbf{1 1 . 0 0}$ & 34.7 & 42.1 & 40.4 & 42.3 & 38.4 \\
\hline $\mathbf{1 1 . 3 0}$ & 39.4 & 38.3 & 40.1 & 43.4 & 39.4 \\
\hline $\mathbf{1 2 . 0 0}$ & 43.1 & 38.6 & 37.7 & 45.1 & 40.4 \\
\hline $\mathbf{1 2 . 3 0}$ & 47.3 & 37.7 & 41.7 & 47.4 & 42.2 \\
\hline $\mathbf{1 3 . 0 0}$ & 39.4 & 44.6 & 43.5 & 46.7 & 43.3 \\
\hline $\mathbf{1 3 . 3 0}$ & 42.3 & 40.7 & 42.1 & 44.4 & 42.3 \\
\hline $\mathbf{1 4 . 0 0}$ & 37.5 & 36.7 & 36.9 & 41.7 & 39.3 \\
\hline $\mathbf{1 4 . 3 0}$ & 29.1 & 29.8 & 29.9 & 38.2 & 36.4 \\
\hline $\mathbf{1 5 . 0 0}$ & 31.6 & 28.8 & 30.5 & 37.2 & 34.8 \\
\hline $\mathbf{1 5 . 3 0}$ & 29.7 & 29.7 & 29.9 & 35.3 & 31.2 \\
\hline $\mathbf{1 6 . 0 0}$ & 35.52 & 36.61 & 37.76 & 41.64 & 37.22 \\
\hline
\end{tabular}

Tabel 5. Hasil Pengujian Suhu Permukaan Panel Surya menggunakan air mineral pada pencahayaan matahari langsung

\begin{tabular}{|c|c|c|c|c|c|}
\hline Waktu (s) & $\begin{array}{c}\text { Termometer } 1 \\
\left({ }^{\circ} \mathrm{C}\right)\end{array}$ & $\begin{array}{c}\text { Termometer } 2 \\
\left({ }^{\circ} \mathrm{C}\right)\end{array}$ & $\begin{array}{c}\text { Termometer } \\
3\left({ }^{\circ} \mathrm{C}\right)\end{array}$ & $\begin{array}{c}\text { Termometer } 4 \\
\left({ }^{\circ} \mathrm{C}\right)\end{array}$ & $\begin{array}{c}\text { Termometer } \\
5\left({ }^{\circ} \mathrm{C}\right)\end{array}$ \\
\hline 09.00 & 36.1 & 44.7 & 47.2 & 41.8 & 35.6 \\
\hline 09.30 & 38.8 & 39.8 & 46.7 & 44.2 & 37.2 \\
\hline 10.00 & 37.2 & 52.2 & 44.6 & 43.5 & 39.8 \\
\hline 10.30 & 42 & 40.6 & 49.4 & 46.2 & 41.2 \\
\hline 11.00 & 42.6 & 50.8 & 48.5 & 47.2 & 42.3 \\
\hline 11.30 & 47.4 & 46.4 & 48.1 & 49.4 & 43.6 \\
\hline 12.00 & 51 & 46.3 & 45 & 52.2 & 45.4 \\
\hline 12.30 & 55.9 & 45.6 & 49.5 & 55.4 & 47.4 \\
\hline 13.00 & 47.6 & 52.8 & 51.3 & 52.3 & 49.1 \\
\hline 13.30 & 50 & 48.9 & 47.4 & 49.7 & 48.2 \\
\hline 14.00 & 45.4 & 44.8 & 44.9 & 47.8 & 46.6 \\
\hline 14.30 & 37.8 & 37.3 & 39.7 & 46 & 43.5 \\
\hline 15.00 & 39.1 & 36.6 & 38.5 & 42.6 & 40.5 \\
\hline 15.30 & 37.4 & 37.5 & 37.2 & 39.3 & 38.7 \\
\hline 16.00 & 43.45 & 44.59 & 45.57 & 46.97 & 42.79 \\
\hline
\end{tabular}

Tabel 6. Hasil Pengujian Suhu Permukaan Panel Surya Menggunakan air laut pada pencahayaan matahari langsung

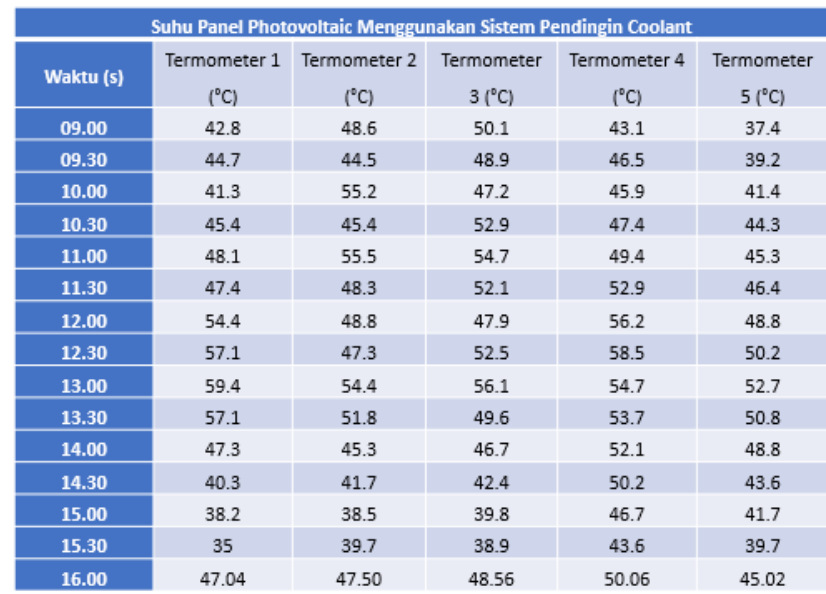


RESISTOR (elektRonika kEndali telekomunikaSI tenaga liSTrik kOmputeR) Vol. 1 No. 2 e-ISSN : 2621-9700, p-ISSN : 2654-2684

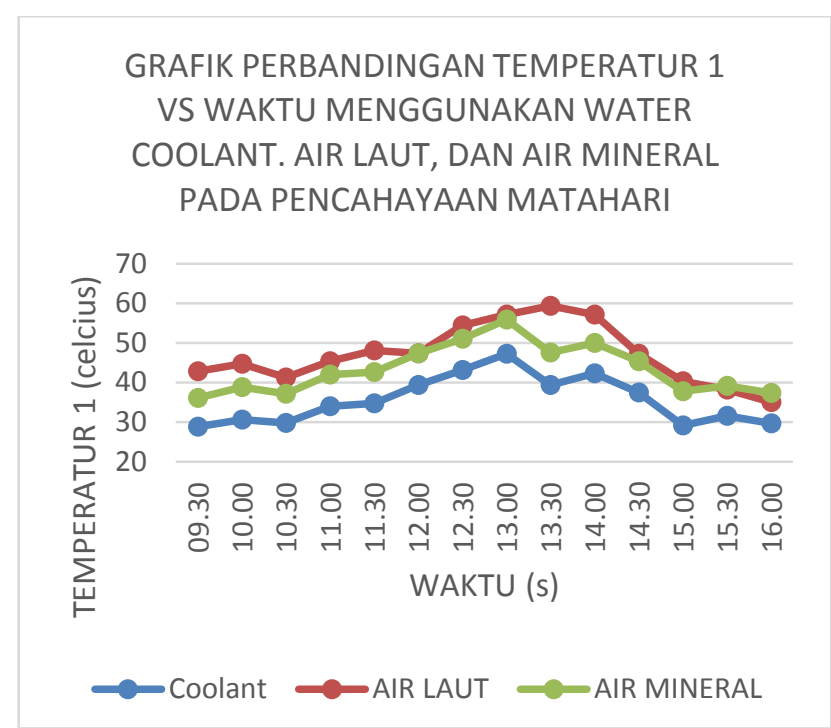

Gambar 18. Perbandingan temperatur 1 menggunakan water coolant, air mineral, dan air laut dengan penyinaran matahari langsung.

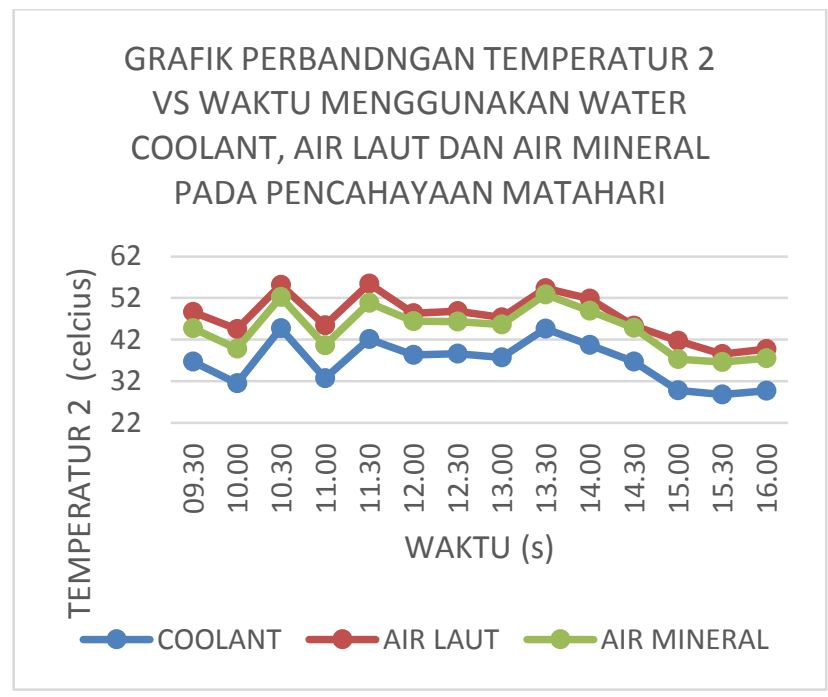

Gambar 19. Grafik perbandingan temperature 2 menggunakan water coolant, air mineral, dan air laut dengan penyinaran matahari langsung.

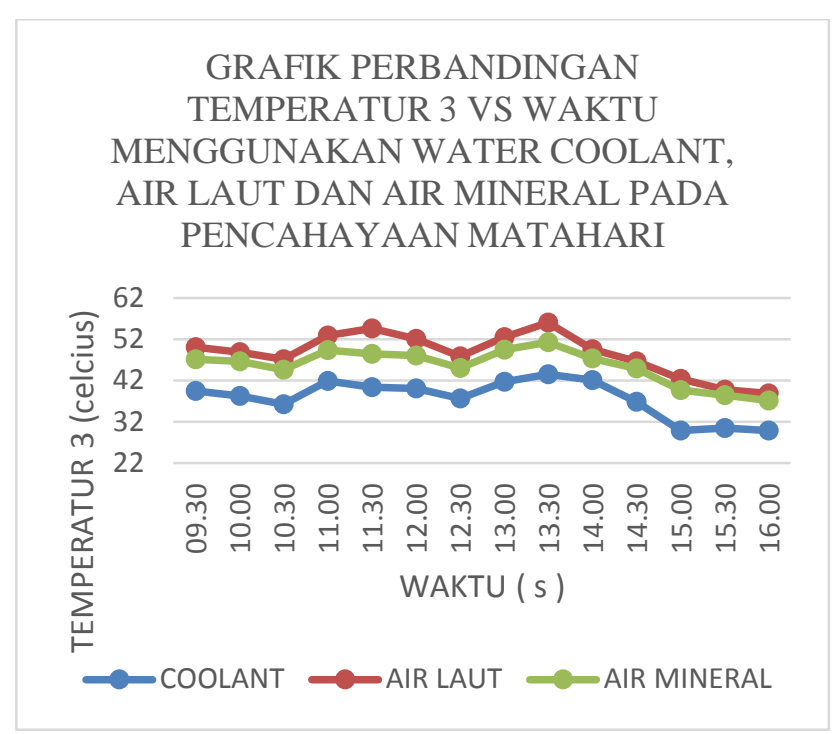

Gambar 20. Grafik perbandingan temperature 3 menggunakan water coolant, air mineral, dan air laut dengan penyinaran matahari langsung.

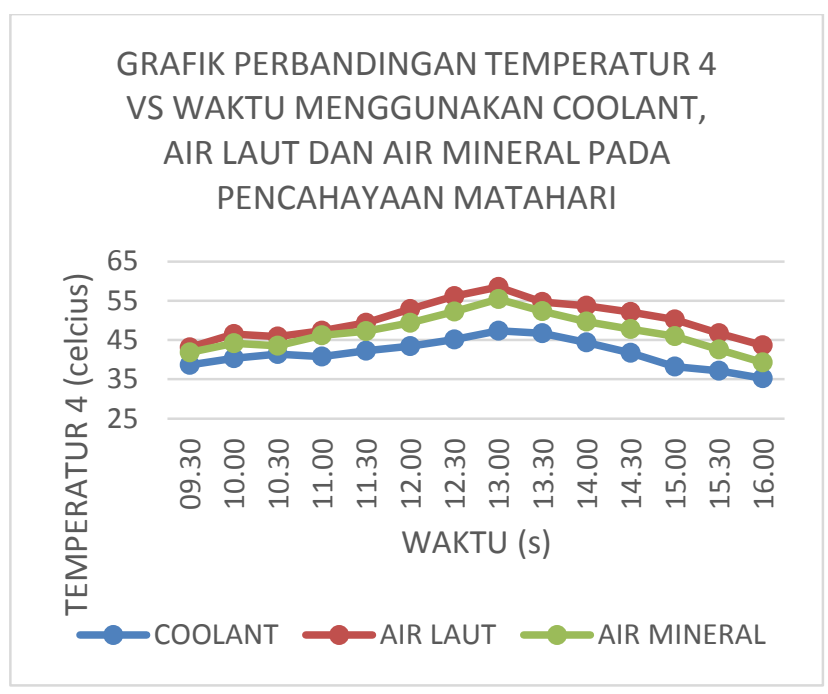

Gambar 21. Grafik perbandingan temperature 4 menggunakan water coolant, air mineral, dan air laut dengan penyinaran matahari langsung. 
RESISTOR (elektRonika kEndali telekomunikaSI tenaga liSTrik kOmputeR) Vol. 1 No. 2 e-ISSN : 2621-9700, p-ISSN : 2654-2684

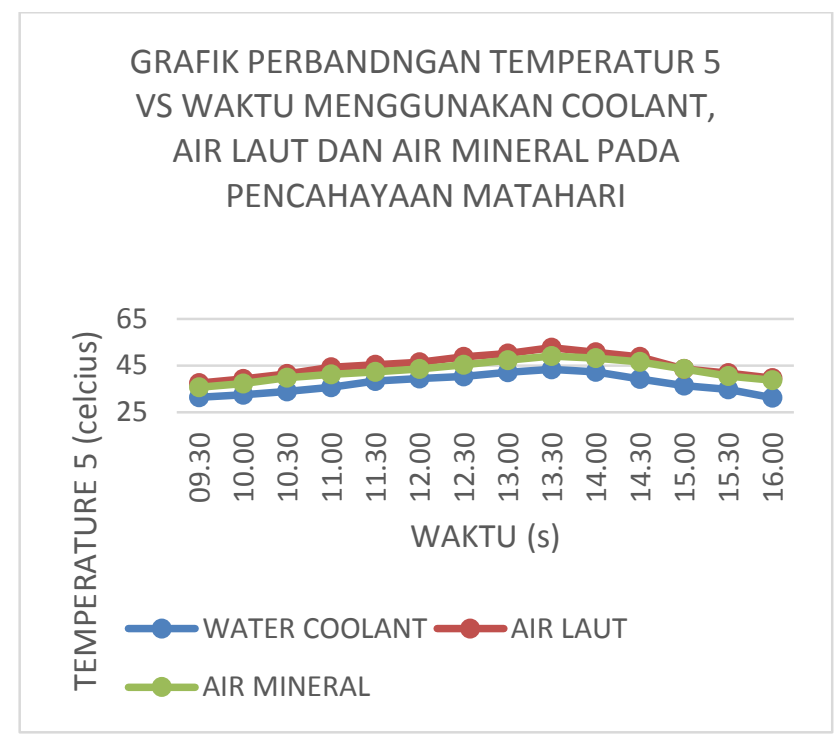

Gambar 22. Grafik perbandingan temperature 5 menggunakan water coolant, air mineral, dan air laut dengan penyinaran matahari langsung.

\section{KESIMPULAN}

Dari seluruh hasil pengujian dan analisa panel surya pada jenis monocrystalline 20Wp menggunakan system pendingin water coolant, air mineal, dan air laut dengan pencahyaan matahari langsung dapat ditarik kesimpulannya sebagai berikut:

1. Dari hasil pengujian dan Analisa pada saat pencahayaan matahari langsung panel surya menggunakan system pendingin panel surya water coolant di dapatkan hasil efisiensi sebesar $14.60 \%$, panel surya menggunakan system pendingin air mineral didapatkan hasil efisiensi sebesar $13.90 \%$, dan panel surya system pendingin air laut didapatkan efisiensi sebesar $13.62 \%$

2. Dari hasil pengujian dan Analisa pada saat pencahayaan matahari langsung panel surya menggunakan system pendingin water coolant mendapatkan hasil yang lebih baik dibandingkan dengan air mineral, dan air laut.

3. Dari hasil pengujian dan Analisa kadar PH air terhadap air mineral dan air laut sebesar 7.4 dan 8.0. dengan hasil tersebut maka kadar $\mathrm{PH}$ air laut tidak cocok untuk panel surya dikarenakan menyebabkan korosi pada prototipe panel surya tersebut.

Dari hasil pengujian dan Analisa pada saat pencahayaan matahari langsung panel surya menggunakan system pendingin water coolant mengalami penurunan suhu permukaan panel pada temperature 1, temperature 2, temperature 3, temperature 4 , dan temperature 5 dibandingkan suhu permukaan panel menggunakan system pendingin air mineral, dan air laut.

\section{DAFTAR PUSTAKA}

[1] M. Pagliaro, G. Palmisano, and R. Ciriminna, Flexible Solar Cells. Weinheim, Germany: Wiley-VCH Verlag GmbH \& Co. KGaA, 2008.

[2] D. Suryana and M. M. Ali, "Pengaruh Temperatur / Suhu Terhadap Tegangan Yang Dihasilkan Panel Surya Jenis Monokristalin (Studi Kasus: Baristand Industri Surabaya)," $J$. Teknol. Proses Dan Inov. Ind. JTPII, vol. 2, no. 1, p. 4, 2016.

[3] J. L. Cruz-Campa et al., "ULTRATHIN FLEXIBLE CRYSTALLINE SILICON: MICROSYSTEMS ENABLED PHOTOVOLTAICS," p. 3.

[4] K. Trautz et al., "High efficiency flexible solar panels," presented at the 2013 IEEE 39th Photovoltaic Specialists Conference, 2013.

[5] K.-H. Tsai et al., "High efficiency of flexible polymer solar cell based on poly(3hexylthiophene)/fullerene," in 2009 34th IEEE Photovoltaic Specialists Conference (PVSC), Philadelphia, PA, USA, 2009, pp. 001678001680.

[6] T. Damas Setyo, "Rancang bangun sistem penangkapan energi maksimum pada solar cell," Universitas Indonesia, 2009.

[7] I. Yusuf and A. Hiendro, "IMPLEMENTASI WATER COOLING SYSTEM UNTUK MENURUNKAN TEMPERATURE LOSSES PADA PANEL SURYA," J. Tek. Elektro Univ. Tanjungpura, vol. 2, no. 1, p. 3, 2017.

[8] F. Fadliondi, H. Isyanto, and B. Budiyanto, "Bypass Diodes for Improving Solar Panel Performance," Int. J. Electr. Comput. Eng. IJECE, vol. 8, no. 5, pp. 2703-2708, 2018. 